DOI https://doi.org/10.30525/978-9934-26-172-5-28

\title{
CURRENT ISSUES OF DEVELOPING MULTIMODAL TRANSPORTATION SYSTEMS IN UKRAINE
}

\author{
Novalska N. I. \\ Candidate of Economic Sciences, Associate Professor, \\ Associate Professor at the Organization of Aviation Works \\ and Services Department \\ National Aviation University \\ Klymenko V. V. \\ Candidate of Economic Sciences, Associate Professor, \\ Associate Professor at the Organization of Aviation Works \\ and Services Department \\ National Aviation University
}

Moskalenko O. I.

Doctor of Pedagogical Sciences, Professor,

Professor at the Organization of Aviation Works and Services Department

National Aviation University

Kyiv, Ukraine

The development of multimodal transport systems is one of the key areas of development of the world transport system. This process is rapidly developing due to integration processes in the field of interaction of modes of transport. Integration is based on common standards and a single information environment both within the country and internationally.

In Ukraine, the share of multimodal and intermodal transportation in the total volume of cargo traffic is only $0.5 \%$, while in the EU and other developed countries this figure is $10-15 \%$. The development of multimodal transportation systems significantly depends on the level of formation of the components of the multimodal transport network, namely: multimodal transport corridors, multimodal transport hubs, multimodal transport routes, multimodal transport and logistics centers.

The integration of transport for the movement of large material flows is organized through international transport corridors, which are the part of multimodal freight systems. Currently, the international transport corridor is considered as part of the global geological space, which means the transition from the transport concept to logistics, or transport and logistics, i.e. from the 
standpoint of the whole process of trade and integration of transport and distribution processes.

The following international transport corridors pass through the territory of Ukraine, such as: Trans-European transport corridor №3 (railway section), corridor № 5 (railway and road section), corridor №7 Danube (water section), corridor № 9 (railway and road section); international transport corridor "Baltic Sea - Black Sea" (railway and road section); transport corridor "Europe Caucasus - Asia (TRACECA)" (railway, road, water section); international transport corridor "Europe-Asia" (railway and road section); international transport corridor "Black Sea Economic Cooperation" (water area).

In the world market there is a tendency to create or expand existing multimodal transport corridors. Thus, in March 2021, a new international multimodal route "North-South Multimodal Route NS Express" ("North-South Express") has been started, which is an international multimodal corridor "Turkey-UkrainePoland". It connects the sea ferry Kaakasu (Turkey) - the port of Black Sea (railway ferry complex) - Slavkuv (Poland) - the countries of the European Commonwealth and Scandinavia. This project involves the use of road, rail and sea modes of transport. The route provides a permanent transport connection and continuous delivery of goods once a week with a transit delivery time of 5 days.

The development of transport corridors and their entry into the international transport system is recognized as a priority direction of national development of transport infrastructure of Ukraine [1]. However, the transit potential of Ukraine is currently used only by $60 \%$. Revenues from transit and a range of services related to international transport corridors account for 6-10\% of Ukraine's GDP. The main factors determining Ukraine's losses in transit flows through international transport corridors are: changes in the world freight market, intensification of international competition for additional transit flows, low interoperability of Ukraine's transport system as part of international supply chains, underdevelopment of infrastructure of the Ukrainian part of the system of international transport corridors, low quality of internal transport network, limited speed of transit traffic, technically obsolete rolling stock, low level of development of the state border infrastructure, lack of sustainable financing for the development of transport sector; low level of development of transport and logistics technologies and objects of multimodal transportations in Ukraine.

Significant influence upon the development of multimodal transportation is made by foreign policy factors, namely: terrorist aggression by Russia, as a result of which the entire transport infrastructure of Donbass is being destroyed; there are difficulties with the use of transport corridors "Black Sea Economic Cooperation" and "Europe-Asia". As a result of the occupation, 
transit capacity of international transport corridors through Ukraine has decreased, in particular: Trans-European corridor № 3 was used only by $10.3 \%$ (201.8 million tons), corridor № 5 - by $29 \%$ (38.4 million tons), corridor № 9 - by $18 \%$ (100.1 million tons), the Baltic Sea - Black Sea corridor - by $4.4 \%$ (92.9 million tons) and the TRACECA corridor by $15 \%$ (204.35 million tons) [2].

Multimodal transport hubs are the direct points of interaction between different modes of transport, transport networks and transport equipment, where cargo is transferred from one mode of transport to another. In Ukraine, the largest transport hubs are multimodal transport hubs which are located in Berdiansk, Dnipro, Zaporizhzhia, Kyiv, Kremenchuk, Lviv, Mariupol, Mykolaiv, Odessa and Cherkasy, in which three or more modes of transport interact.

The most complex transport hubs, where different modes of transport intersect, are sea ports. According to the results of 2019, the volume of cargo handling in 13 operating Ukrainian ports (except for ports located in the Crimea) amounted to more than 160 million tons, which was a historic record. The maximum volumes of transshipment were provided by: the port of the South - 53.9 million tons, Mykolayiv - 33.4 million tons, Black Sea 26.2 million tons, Odessa - 25.3 million tons, Mariupol - 6.5 million tons.

The global multimodal transportation system is developing rapidly, reformatting the multimodal transportation infrastructure to its needs and improving global logistics. According to the World Bank's Logistics Performance Index (LPI), Ukraine ranks 66th in the world with 2.83 points, indicating significant problems in the domestic logistics system, and as a result, this leads to delays in transportation and additional costs.

Current processes of Ukraine's integration into the international transport and logistics system, strategic goals of neighboring countries, determine the feasibility of forming in the border regions of our country transport and logistics clusters, rather than individual transport and logistics hubs [3, p. 283].

Important tasks in terms of developing multimodal transport systems in Ukraine include:

- creation of a single network of multimodal transport hubs, in particular, on interregional, national and international scale;

- development of multimodal logistics centers based on the study of their capacity and design of the necessary locations;

- introduction of pricing policy in the field of multimodal freight transportation, which would focus on minimizing costs in trade with Ukraine;

- creating conditions for the development of transport and logistics activities and competitive domestic providers of logistics services; 
- reform of customs and transit processes, including comprehensive implementation of the "single window" system;

- development of a network of routes of regular container and piggyback freight trains in international traffic;

- creation of a single information system of technological interaction of different modes of transport;

- formation of transport and logistics clusters;

- attracting domestic and foreign investments to finance projects in the field of multimodal transport systems, the use of public-private partnership mechanisms.

\section{References:}

1. Національна Транспортна Стратегія України до 2030 року, схвалена розпорядженням КМУ від 30 травня 2018 р. № 430-р. URL: https://zakon.rada.gov.ua/laws/show/430-2018-\%D1\%80\#Text

2. Вінниченко Л.Ф. Динаміка ефективності розвитку логістики в Україні. URL: http://www.confcontact.com/2016-ekonomikaimenedzh ment/2_vinnichenko_korzh.htm

3. Копитко B.I. Формування транспортно-логістичних систем в умовах реформування залізничної галузі. Вісник Дніпропетровського національного університету залізничного транспорту імені академіка В. Лазаряна. 2012. Вип. 40. С. 281-284. 